\title{
CIP 充填体のコンピュータ・シミュレーション
}

\author{
浜田美明什・石㠃幸三・ホセブリセニョ** \\ ( 長岡技術科学大学機械系材料設計大講座, 940-21 長岡市上富岡町 1603-1 \\ *長岡技術科学大学大学院, 940-21 長岡市上富岡町 1603-1 \\ **(株) リクルート
}

\section{Computer Simulation of CIP Densified Bodies}

\author{
Yoshiaki HAMADA*†, Kozo ISHIZAKI and José BRICEÑO**
}

\footnotetext{
Department of Materials Science and Engineering, School of Mechanical Engineering,

Nagaoka University of Technology, Kamitomioka-cho, Nagaoka-shir 940-21

* Graduate Student, Nagaoka University of Technology, Kamitomioka-cho, Nagaoka-shi

** Recruit Co. , Ltd.

A computer simulation of a Cold Isostatic Press (CIP) densified bodies was carried out to estimate the initial relative density and the cocrdination number which are important factors to elaborate HIP maps. First, the mean coordination number and the packing fraction of CIPped bodies were calculated.

Secondly, these values were compared to those of other simulations for unidirectional packing model. Two assumptions were used to simulate CIPped bodies. They were (a) all particles were rigid spheres of the same size, and (b) they were moved initially toward the center to contact three other particles.

The results were as follows:

(1) The relative density and the mean coordination number of simulated CIPped bodies are 0.56 and 6.5, respectively.

The coordination number is higher than the value obtained for an unidirectional packing model.

(2) The present model gives a reasonable relative density and coordination number for a CIPped body.

(3) The relative density and the mean coordination number of simulated CIPped bodies give good agreement with the initial state used in the HIP maps.

[Received January 30, 1989 ; Accepted January 25, 1990]

Key-words : CIP, HIP map, Relative density, Coordination number, Computer simulation, Particle packing

\section{1. 緒 言}

粉体を充填して求められる相対密度と配位数の関係に ついては，種々の知見がある。例えば Scott らは，鋼球 を円筒容器に詰め込んで充填体を作製し，得られた相対 密度, 配位数について評価している1) 3). またコンピュー 夕の発達に伴い, コンピュータ・シミュレーションによ る相対密度, 配位数の評価についても報告されてい $ろ^{4), 5)}$.

充填した粉体を焼結させる方法として Hot Isostatic Press (HIP) 焼結があるが，HIP 焼結は異方性のない 均質材料を得る有力な手段として多方面で利用されてい る. HIP 焼結過程の理論的考察としてはHIP マップが あり，固相焼結の理論的考察としてはAshby らの HIP マッフプ(6),7), 液相焼結の理論的考察としては田中, 石㠃 の HIP マップがある ${ }^{8)}$. Ashby らは焼結初期において

†現住所：日清製粉 (株) 生産技術研究所粉体研究室, 354 埼 玉県入間郡大井町鶴ヶ岡 5-3-1

Present Address : Nisshin Flour Milling Co., Ltd., 5-3-1, Tsurugaoka, Oi-machi, Iruma-gun, Saitama 354
の相対密度，配位数を Scott のモデル実験值を参考に， 粒子はちょう密無秩序充填状態に詰め込まれているとい う仮定 ${ }^{1)}$ もとに設定し，解析している ${ }^{6), 7)}$.

HIP 焼結の初期過程では, 粉体には等方圧がかかっ ており，粉体は等方的に充填されるもの亡考えられる。 しかし，これまで得られた相対密度と配位数の関係は， そのほとんビが一軸方向に充填する重力充填体を作製し て評価している。また Scott のモデル実験值 ${ }^{11,2)} も 一$ 軸 方向に鋼球を充填して求められており，基本的には一軸 充填と考えられ，成形体の相対密度が HIP マップの結 果に非常に敏感であるにもかかわらず，HIP 焼結の初 期充填として十分理解された数值を使っていない，そこ で本研究では，HIP 焼結と同じ等方充填機構を持つ Cold Isostatic Press (CIP) 成形について着目し, 単 一球を等方的に充填して等方圧充填体を作製し，得られ た結果を一軸 (重力) 充填体と比較した。また HIP 焼 結の初期充填として充填体内部での相対密度と配位数に ついて評価し，HIP マップの初期条件値への応用を考 
えた。

\section{2. 計算方法}

等方加圧によるち密化は次のように考えた。粒子は変 形不可能な剛体であり，CIP 圧力による粒子の変形は ないものとする。等方加圧による粒子の配列変化をモン テ・カル口法を用いて再現し，加圧による配列変化によ りち密化が進行するものと仮定している.

充填体を構成する各粒子は，乱数を用いてランダムに 空間に配置される。空間に配置された各粒子は粒子群の 中央に位置する点を原点として, 原点方向に 1 粒子ずつ 移動する(図 1(a))。移動した粒子A は最初の粒子Bに 接触し (図 $1(\mathrm{~b})$ )，その後接触粒子周りに任意の方向に 転がり，2 番目の粒子Cに接触するまで転がる(図 1 (c)). そしてこの二つの接触粒子 B, $\mathrm{C}$ との接触状態を 保ちながら，接触粒子 B , C の中心を結ぶ直線に垂直な 面に沿って転がり， 3 番目の粒子 D に接触するまで転 がって B , C , D の各粒子と接触する (図 1(d))。このよ うにすべての粒子を最初に他の三つの粒子と接触する位 置に配置した。この過程を 1 粒子ずつ繰り返して行うこ とにより, 多粒子の CIP 充填体をシミュレートしてい る.

シミュレートされた充填体の相対密度の計算は, 充填 体を形成する各粒子を充填体の中心から近い順に順番付 けし, 充填体の中心から充填体を構成する任意の粒子の 中心までの距離を半径とする大きな球を仮定したとき に，この球の体積とその内側に中心を持つすべての粒子

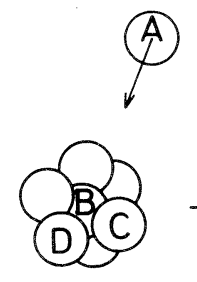

(a)

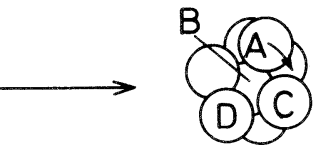

(b)

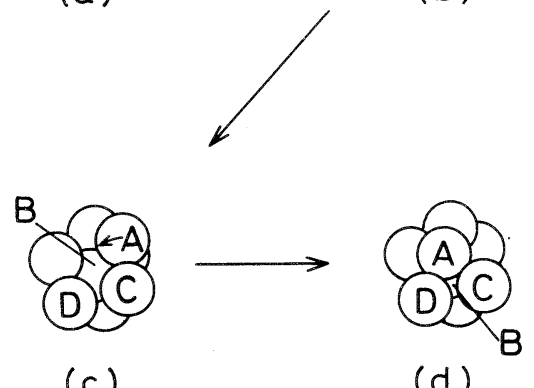

(c)
が占める体積の比で表されている.

なお，この計算はFortran を用い，東京大学大型計算 機センターHITAC M-682 H を使用して行った。

\section{3. 結果及び考察}

\section{1 実際の CIP 成形における相対密度}

本研究では,粒子は剛体球を仮定しているので, シミュ レートする粉体として, 塑性変形の非常に少ない $\mathrm{Si}_{3} \mathrm{~N}_{4}$ や $\mathrm{SiC}$ 等のセラミックスが考えられる. CIP 成形を HIP の前処理として考えた場合, いかにして均質な充 填体を得るかが重要となる。 その尺度として相対密度が ある，著者らは構造用セラミックスである $\mathrm{Si}_{3} \mathrm{~N}_{4}$ を CIP 成形し, 実際に相対密度を測定した。印加圧力は 2000，4000，6000 気圧に分けて求めた。その結果印加圧 力が 2000 気圧での相対密度は $0.50,6000$ 気圧では 0.55 であり，圧力による相対密度の変化はそれほど大きくな いことが確認された。

\section{2 等方圧充垻体内部での相対密度と配位数の関係}

粒子数 2600 個でシミュレートした場合の, 充填体内 部での相対密度之配位数の関係を図 2 に示す。横軸には 充填体の中心から各粒子の中心までの距離が短いものか ら順に粒子に番号を付け，その個数を基準として取って いる. 縦軸にそれぞれ相対密度, 平均配位数を取ってい る。

この図から次のことがわかった。相対密度は充填体の 中心部近傍でちょう密無秩序充媜状態（相対密度 0.64） に近い值を示しており, 相対密度は充填体の内側から外 側に向かうにつれて, 徐々に下がっていく。減少の傾き は徐々に小さくなっていき, 充填体の中心からのある位 置でほぼ一定の值を示すようになる。 また平均配位数も 充填体の内側から外側に向かうにつれて徐々に下がり， ある位置でほぼ一定の值を示す。

このように本モデルでは, 充填体の内側では密で外側 に向かうにつれて疎になる充填体を形成した。これは本

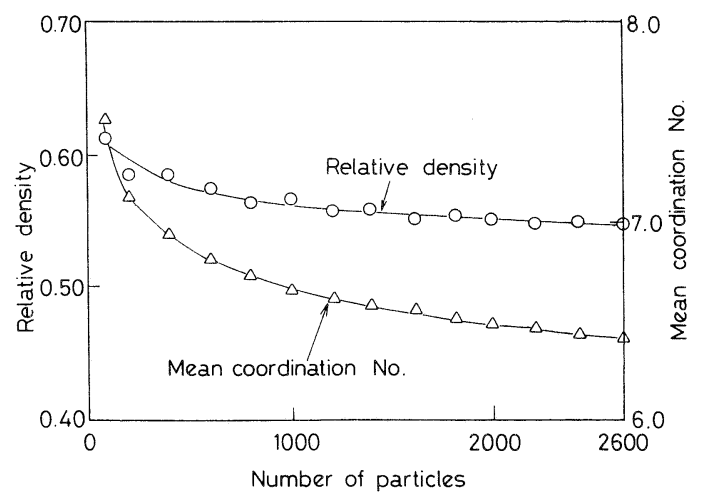

Fig. 2. Relationship between the relative density and the mean coordination no. in the simulated body. $\bigcirc$ : Relative density, $\Delta$ : Mean coordination no.

Fig. 1. Movement of a particle. (a) Transfer of a particle (Particle A) toward the center, (b) First contact with the particle B, (c) Second contact with both particles B and C, (d) Third contact with three particles $\mathrm{B}, \mathrm{C}$ and $\mathrm{D}$. 
モデルで採用した充填の方法が，等方圧の効果を出すた めに粒子を一点に対して集めたことによる。実際の等方 充填の効果を出すためには, 充填体表面に位置する粒子 に作用する圧力についてシミュレートすべきであるが， 本モデルでは計算機の能力上一点に対して粒子を移動さ せる手法を取った。実際の CIP 成形体においては，表 面か密で内側が疎になる充媜体を形成すると考えられ， 内部で充填状態が一定ではなく, 徐々に变化しているも のと思われる。本結果ではシミュレートされた充填体の 内側が CIP 成形体の表面部に対応し, 表面部が CIP 成 形体の中心付近に対応すると考えられる。しかし結果之 して得られる相対密度, 平均配位数がほぼ一定になる部 分を使うかぎり充填体内部での相対密度の分布の影響は 避けられ、等方圧充填体としての取り扱いが可能と考え られる。

\section{3 単一球の充墴に関する他報告との比較}

図3に単一球の充填に関する種々の報告について示し ている。図のムと $\Delta$ は鋼球を円筒容器に充填して接触状 態に配置したS cott のモデル実験值を示す．ムは円筒容 器に鋼球を充填して得られた $\triangle の$ 充填体に, 更に円筒容 器に振動を与えてもつと密な充填体を得たもので, その ときの相対密度は 0.64 , 配位数は 6.4 となっている. これが Close packing 状態であり, 容器に振動を与えな い疎な充填 $\triangle$ が Loose packing 状態である。このとき の相対密度は 0.60 , “配位数 5.5 となっている"1.またコ ンピュータ・シミュレーションにより単一球を一軸方向 に充填して求められた重力充填体の代表的な值はつであ $\eta$, 相対密度 0.58 , 配位数 6.0 が得られている ${ }^{4) .51}$.

これらの值と比較して本研究結果（ $\square$ 印）では, 相対 密度 0.56 のときに配位数 6.5 が得られた。つまり等方 的に充填したモデルにおいては, 重力（一軸）充填体に 比べ, 相対密度が低いわりに高い配位数が得られるとい

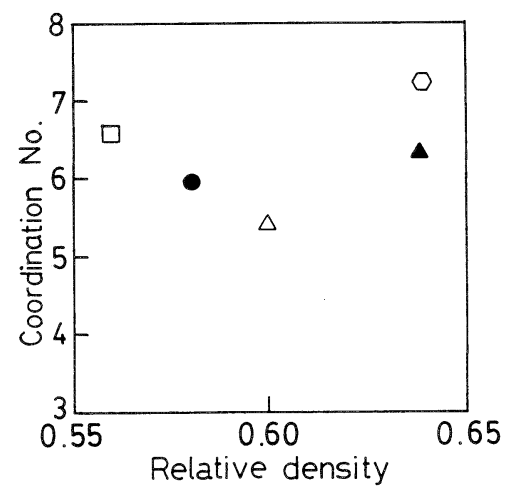

Fig. 3. Comparison of results on relative density and coordination no. in various packing methods of same sized spheres. $\square$ : Present work, : Computer model of a gravitational force, ${ }^{4,5)} \triangle:$ Scott (loose packing), ${ }^{2\}} \boldsymbol{\Delta}$ : Scott (close packing), ${ }^{1)} \bigcirc$ : Value of the HIP map used by Ashby et al. ${ }^{7)}$
うことがわかる. Ashby らの HIP マップにおいて初期 の相対密度, 配位数はS cott のモデル実験值"を基に相 対密度 0.64 , 配位数 7.3 が仮定されている6!.これは○ で示されている.この配位数 7.3 は S cott の累積半径分 布関数 ${ }^{2}$ を参考に, その後の Arzt の解析により設定され たものである!.

\section{4 累積半径分布関数}

各粒子周りにおける他粒子の近接状態を見るのに, 累 積半径分布関数がある.これは図 4 に示すように単一球 の半径を $R$ としたときに, 球の中心からの距離 $r$ を 徐々に増加させていき, その距離 $r$ の内側に中心を持 つ近接粒子の数 $G(r)$ を示している. Arzt はHIP マッ プの初期配位数を 7.3 と設定している ${ }^{91}$ が，これは次に 示す累積半径分布関数 (図 $5(a)$ ) 加, 解析的に求め られたものである. 図 5(a) はS cott のモデル実験值の 累積半径分布関数 ${ }^{21}$ と本研究値について比較している。 横軸に距離 $r$ を球の直径 $2 R$ を基準として取っており, 縦軸に近接粒子の数 $G(r)$ を取っている. 図 $5(\mathrm{~b})$ には $r=2 R$ の近傍においての拡大図を示している.

最初にS cott の值について考察してみる. 球の中心か ら十分遠い点での相対密度 $D$ は近似的に,

$$
D=G(r)(4 / 3) \pi R^{3} /(4 / 3) \pi r^{3}
$$

で求められるが, このとき相対密度 $D$ がちょう密無秩 序充填 $(D=0.64)$ であると仮定すると, 近接粒子の数 は図 5(a) 中の式

$$
G(r)=0.64(r / R)^{3}
$$

式で表される. Artz はここで Scott の值 ${ }^{2}$ が横軸が 1 の 近傍では（7）式からずれていることに着目し, この付 近では

$$
G(r)=7.3+15.5(r / 2 R-1)
$$

式で表した ${ }^{91}$.これから $r=2 R$ の点での接触粒子の数 7.3 が得られた. 本研究では図 2 に示されるように, 5ょ う密無秩序充填状態より低い值を取っているので, Scott の值に比べて近接粒子の数も低い傾向を示してい る。しかしここで注目すべきは, 図 5(b) に示されるよ うに, 等方圧充填体では $r=2 R$ の点において $\operatorname{Scott}$ の

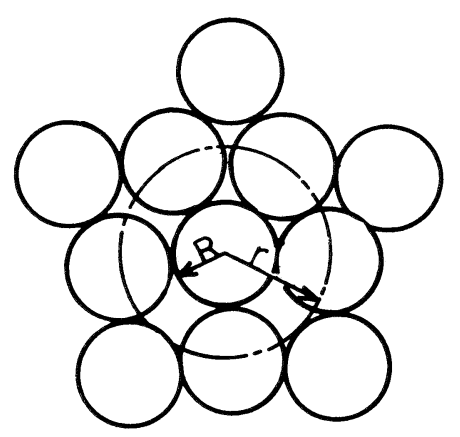

Fig. 4. The packing model of particles. $R$ is the radius of a particle and $r$ is the distance from the center. 


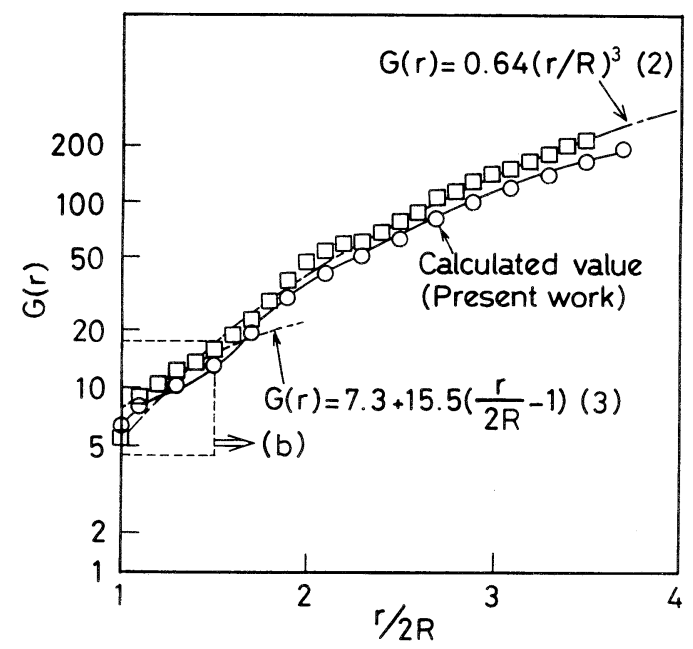

(a)

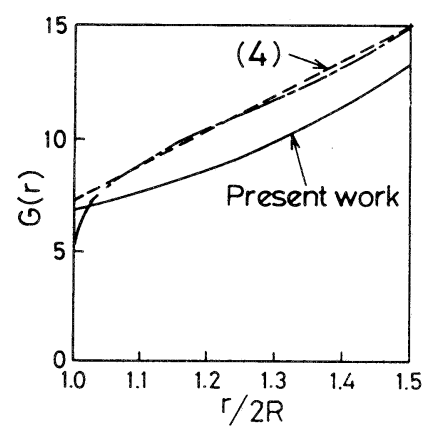

(b)

Fig. 5. (a) Radial distribution function $G(r)$ as a function of $r / 2 R$. $\bigcirc$ : Calculated value by the present work, $\square$ : Experimental value by Scott. ${ }^{1)}$ The dashed and dotted line indicates Eq. ( 2 ) and the dashed line indicates Eq. ( 3$)$. The region of small $r(<3 R)$ is shown in (b).

值 ${ }^{2)}$ よ接触粒子の数が多く(配位数が高い), HIP ち 密化過程を理論的に解析するために用いられた Arzt の 值 $7.3^{9}$ に近いという点である. Arzt は $Z=7.3$ を仮定 し, 焼結途中における密度の解析的な算出を試みてい る ${ }^{9)}$ が，実際に CIP 成形体では，圧力を加えて粒子を固 めるため粒子の移動が起こり, 重力充填体よりも配位数 は上がるはずである．すなわち充媜体を形成する各粒子 に近接（接触）する粒子の数は増す。このことから $r$ $=2 R$ の点における接触粒子の数は Scott $の$ 值よりも高 いことが考えられ，等方圧充填体の配位数は高くなる.

\section{5 固相焼結 HIP モデルのなかでの相対密度と配位 数の関係}

Helle は, 相対密度 $D$ と配位数 $Z$ の関係を以下の簡 単な式で近似した7!

$$
Z=12 \mathrm{D}
$$

この式は 3 次元で単一球が最ちょう密状態になったと

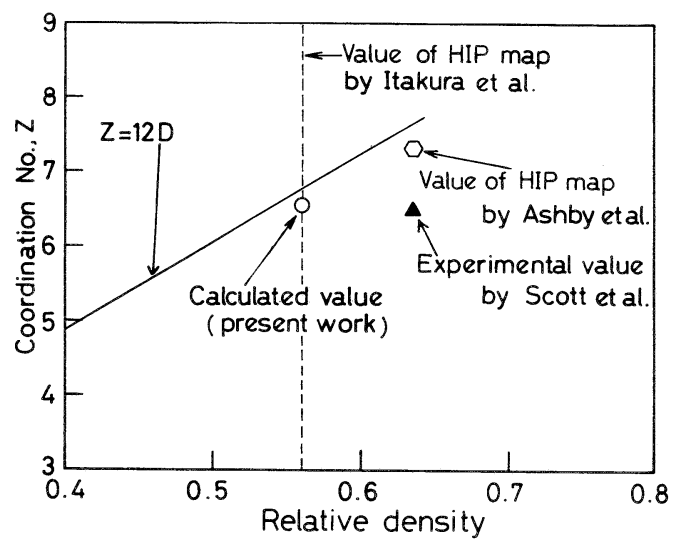

Fig. 6. Relationship between the coordination no. and the relative density. The line represents $Z=12 \mathrm{D}$. The open circle corresponds to the values of the present work. Experimental data by Scott et al. and the value used in the HIP map by Ashby et al. $\left(D_{0}=0.64\right)$ are also indicated. The dashed line indicates the value used in the HIP map by Itakura et al. $\left(D_{0}=0.56\right)$.

き，配位数は 12 となるが，この最ちょう密状態におい て，相対密度 $D$ が 1 になることを表している．本モデ ルの仮定に従うと, 最密充填の時の相対密度は $D=$ 0.74 となるべきであるが, Helle は $D=1$ のときに $Z=$ 12 となると仮定した。

図 6 に本研究により得られた充填体の相対密度，平均

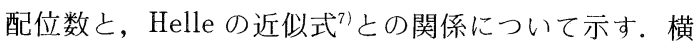
軸に相対密度，縦軸に平均配位数をそれぞれ取ってい る.

この図から本研究により得られた充填体内部での相対 密度と配位数の関係は, Helle の近似式 ${ }^{7)}$ ほぼ一致し ていることがわかる.この近似式において，ちょう密無 秩序充填状態 $D=0.64$ では $Z=7.7$ であり, 固相焼結 の HIP マップにおける Arzt の仮定 $Z=7.3^{91}$ に近い值 を示す。また $D=0.56$ のときに $Z=6.7$ であり，本研 究値 $D=0.56$ で $Z=6.5$ に近い値を示している. 同様 にS cott のモデル実験值 ${ }^{1)}$ と等方的に充填した本研究值 との比較によると, 同じ相対密度でも Scott の值は平均 配位数が低くなり ${ }^{31}$, Helle の近似式 ${ }^{71}$ から大きくずれる ことがわかる.

Ashby 理論におけるち密化速度式は, 相対密度 $D$ が $D<0.9$ の場合には以下の式で表される6).

初期段階 $(\mathrm{D}<0.9)$

$$
\dot{D}=\frac{43\left(1-D_{0}\right)^{2}\left(\delta D_{\mathrm{b}}+\rho D_{\mathrm{v}}\right)}{\left(D-D_{0}\right)^{2}\left(k T R^{3}\right)} \Omega P
$$

$\dot{D}$ はち密化速度 $\left(\mathrm{s}^{-1}\right), D_{0}$ は成形体の相対密度, $\delta$ は 粒界の幅 $(\mathrm{m}), D_{\mathrm{b}}$ は粒界拡散係数 $\left(\mathrm{m}^{2} \mathrm{~s}^{-1}\right), \rho$ はネッ クの曲率半径 $(\mathrm{m}), D_{\mathrm{v}}$ は体積拡散係数 $\left(\mathrm{m}^{2} \mathrm{~s}^{-1}\right), k$ は ボルツマン定数, $T$ は絶対温度 $(\mathrm{K}), R$ は粒子の半径 
$(\mathrm{m}), \Omega$ は原子の体積 $\left(\mathrm{m}^{3}\right), P$ は印加圧力 $(\mathrm{MPa})$ について示している.この式から $D_{0}$ の值がち密加速度 へ及ぼす影響が推察される.

Ashby 理論における成形体の相対密度は $D_{0}=0.64$ (ちょう密無秩序充填状態) が設定されている7). しか しこれは対象とする成形体に関する理論的な根拠がある わけではなく，充填に関してこれまで得られた一般的な 知見から仮定されたものである.

実際に塑性変形の非常に少ない粉体を充填した場合, これよりも低い相対密度を示すことが考えられ，これは 本研究においても $\mathrm{Si}_{3} \mathrm{~N}_{4}$ の CIP 成形体の実測値から確 認されている。このとき印加圧力を 6000 気圧程度まで 上げても, 相対密度は 0.55 であった. 塑性変形の非常 に少ない $\mathrm{Al}_{2} \mathrm{O}_{3}$ を $\mathrm{HIP}$ 焼結して求められた板倉らの HIP マップ'0)では, 図 6 中の破線で示したように， $D_{0}$ $=0.56$ を仮定している.この值は金型を用いて一軸方 向に成形した試料を CIP 成形したものの実測值であり, 塑性変形の非常に少ない粉体を仮定した本モデルの相対 密度 0.56 (図 2 ) と一致した.

これらのことから等方的に充填した CIP 充填体モデ ルでは, HIP 処理初期における等方加圧状態を模倣し ており, 塑性変形のほとんどない粉体を対象とした場合 の HIP マップの初期值として適当であると考えられる.

\section{4. 結 言}

モンテカルロ法を用いたコンピュータ・シミュレー ションにより等方圧充填体を作製し, 充填体内部での相 対密度と配位数について調べた．またその值を固相焼結 の HIP マップへ応用することを考えた。 その結果, 以
下の結論を得た.

(1) CIP 充填においては重力 (一軸) 充填体に比 べて, 同じ相対密度でも平均配位数が高くなる，相対密 度 0.56 のときに配位数 6.5 であった。

(2) 本研究で得られたシミュレーション・モデル は, 実際の CIP 成形体の相対密度, 配位数として適当 である。

（３）種々の HIP マップにおける初期条件との比較 の結果, 本研究で得られた CIP 成形体の相対密度は, $\mathrm{Al}_{2} \mathrm{O}_{3}$ の HIP マップに用いられている CIP 成形体の相 対密度 $D_{0}=0.56$ によく一致し, 塑性変形の非常に少な い粉体を仮定した場合の HIP マップの初期条件として 与えられる相対密度, 配位数として適当であると考えら れる.

\section{文献}

1) G.D. Scott and D. M. Kilgour, Br. J. Phys. D, 6, 863-66 (1969).

2) G. D. Scott, Nature, 194, 956-57 (1962)

3) G. Mason, Nature, 217, 733-35 (1968).

4) J. Rodriguez, C.H. Allibert and J. M. Chalx, Powder Technol., 47, 25-33 (1986).

5) M. J. Powell, Powder Technol., 26, 221-22 (1980).

6) E. Arzt, M.F. Ashby and K. E. Easterling, Met. Trans., 14a, 211-21 (1983).

7) A.S. Helle, K.E. Easterling and M. F. Ashby, Acta Met., 33, 2163-74 (1985).

8）田中紘一, 石㟝幸三, 「液相焼結における HIP 機構図 一窒化ケイ素の焼結——」, 「新素材焼結一-HIP 焼結 の基礎と応用一」, 石㠃幸三, 田中紘一編, 内田老鶴围, (1987), pp. 7-38.

9) E. Arzt, Acta Met., 30, 1883-90 (1982).

10）板倉一久, 内田 希, 植松敬三, 斉藤勝一, 宮本 明, 宮下恒雄，セラミックス論文誌，96，574-78 (1988). 